\title{
Geotechnology applied to land classification in areas of the Atlantic Forest in southeastern Brazil
}

\author{
Geotecnologia aplicada à classificação das terras em áreas da Mata Atlântica no sudeste do Brasil \\ Geotecnología aplicada a la clasificación de tierras en áreas de Mata Atlántica en el sureste de Brasil
}

Received: 05/09/2021 | Reviewed: 05/13/2021 | Accept: 05/14/2021 | Published: 05/30/2021

\author{
Nivaldo Schultz \\ ORCID: https://orcid.org/0000-0002-3685-680X \\ Soils Department, Federal Rural University of Rio de Janeiro, Brazil \\ E-mail: nsufrrj@yahoo.com.br \\ Kellis Fernanda Amancio Moreira \\ ORCID: https://orcid.org/0000-0002-8840-1356 \\ Soils Department, Federal Rural University of Rio de Janeiro, Brazil \\ E-mail: kellisfernanda@hotmail.com \\ Isabela Beatriz Pereira da Cruz \\ ORCID: https://orcid.org/0000-0002-7510-9591 \\ Soils Department, Federal Rural University of Rio de Janeiro, Brazil \\ E-mail:Isabelabia6@hotmail.com \\ Pedro Araújo Garcia \\ ORCID: https://orcid.org/0000-0001-7429-2155 \\ Soils Department, Federal Rural University of Rio de Janeiro, Brazil \\ E-mail:drinpe.a.garcia@gmail.com \\ Luiz Carlos de Souza Filho \\ ORCID: https://orcid.org/0000-0001-7528-5352 \\ Soils Department, Federal Rural University of Rio de Janeiro, Brazil \\ E-mail: souzafilhoagronomia@gmail.com \\ Helena Saraiva Koenow Pinheiro \\ ORCID: https://orcid.org/0000-0002-4577-6019 \\ Soils Department, Federal Rural University of Rio de Janeiro, Brazil \\ E-mail:lenask@gmail.com \\ Otavio Augusto Queiroz dos Santos \\ ORCID: https://orcid.org/0000-0001-9554-303X \\ Soils Department, Federal Rural University of Rio de Janeiro, Brazil. \\ E-mail:otavioqueiroz7@hotmail.com \\ Marcos Gervasio Pereira \\ ORCID: https://orcid.org/0000-0002-1402-3612 \\ Soils Department, Federal Rural University of Rio de Janeiro, Brazil \\ E-mail:mgervasiopereira01@gmail.com
}

\begin{abstract}
The objective of this study was to classify the lands of a micro-watershed located in the Atlantic forest biome, in a region of rough relief, in the use capacity system using geotechnology resources and indicate uses for the lands according to their suitability. The theoretical basis of the Manual for Utilitarian Survey and Classification of Land in the Use Capacity System with adaptations for areas of rough relief was adopted. The study was carried out from the survey of topographic information to construct the altimetric map of the watershed, followed by the survey of the physical environment, especially water erosion, description of soil profiles and collection of samples. The parameters effective depth, texture, permeability, slope, erosion, fertility, and land use were evaluated. Based on the pedological data and on the use of applied geotechnology, the soil map was created, and the lands of the watershed were classified and mapped in the use capacity system. After interpretation of the survey products, it was verified that in rough relief, slope is the predominant factor to determine the classes of land use, as it outweighs the other parameters evaluated. Land classification land with the use capacity system promotes optimization in the use of areas with agricultural areas and preservation of those destined for conservation.
\end{abstract}

Keywords: Land capability; Soil atributes; Atlantic Forest.

\section{Resumo}

O objetivo deste estudo foi classificar as terras de uma bacia hidrográfica localizada em região de relevo acidentado no sistema de capacidade de uso utilizando recursos de geotecnologia aplicada e indicar usos para as terras de acordo com sua aptidão. Foi utilizado o Manual para Levantamento Utilitário e Classificação de Terras no Sistema de Capacidade de Uso com adaptações para as áreas de relevo acidentado. O trabalho foi realizado a partir do levantamento de 
informações geográficas para a elaboração de mapas de altimetria e o modelo digital de elevação da bacia hidrográfica, seguido do levantamento do meio físico, especialmente a erosão hídrica, descrição de perfis de solo e a coleta de amostras. Foram avaliados os parâmetros profundidade efetiva, textura, permeabilidade, declividade, erosão, fertilidade e o uso dos solos. Com base nos dados e utilização de geotecnologia aplicada foi elaborado o mapa de solos e realizada a classificação e o mapeamento das terras da bacia hidrográfica no sistema de capacidade de uso. Foi verificado que em relevo acidentado a declividade é o fator preponderante para determinar as classes de uso das terras, uma vez que se sobrepõem aos demais parâmetros avaliados. Com o emprego do sistema de capacidade de uso verificou-se que é possível otimizar o uso das áreas agrícolas e preservar as destinadas a conservação.

Palavras-chave: Aptidão agrícola; Atributos do solo; Floresta Altântica.

\section{Resumen}

El objetivo de este estudio fue clasificar los terrenos de una cuenca hidrográfica ubicada en una región de relieve accidentado en el sistema de capacidad de uso utilizando recursos de geotecnología aplicada e indicar los usos de los terrenos según su idoneidad. Se utilizó el Manual de Elevación de Servicios Públicos y Clasificación de Terrenos en el Sistema de Capacidad de Uso, con adaptaciones para las áreas de relieve accidentado. El trabajo se llevó a cabo a partir del levantamiento de información geográfica para la elaboración de mapas altimétricos y el modelo digital de elevación de la cuenca hidrográfica, seguido del relevamiento del medio físico, especialmente erosión hídrica, descripción de perfiles de suelos y recolección de muestras. Se evaluaron los parámetros profundidad efectiva, textura, permeabilidad, pendiente, erosión, fertilidad y uso del suelo. Con base en los datos y el uso de la geotecnología aplicada, se elaboró el mapa de suelos y se realizó la clasificación y mapeo de las cuencas hidrográficas utilizando el sistema de capacidad de capacidad. Se encontró que en relieve escarpado la pendiente es el factor principal para determinar las clases de uso del suelo, ya que se traslapan con los demás parámetros evaluados. Con el uso del sistema de capacidad capacidad, se encontró que es posible optimizar el uso de las áreas agrícolas y preservar las destinadas a la conservación.

Palabras clave: Aptitud agrícola; Atributos del suelo; Mata Atlántica.

\section{Introduction}

The concern with soil conservation in agricultural areas dates back to the nineteenth century, especially in the United States of America. At that time American pedologists already warned of the risks of water erosion and its consequences for agricultural production and preservation of natural resources (Bertoni and Lombardi Neto, 2012; Lepsch et al., 2015). This concern with and dissemination of the subject led to the emergence at the time of a classification of lands focused on their agricultural use capacity, prioritizing soil conservation in the Pennsylvania Soil Survey, including the mapping of land use (Gardner, 1998; Lepsch et al., 2015). From these initiatives, two manuals were published to guide the surveys of the physical environment and classification of land in the use capacity system - Soil Conservation Survey Handbook (Norton, 1939) and Land-Capability Classification (Klingebiel and Montgomery, 1961).

In Brazil, land use and occupation became important after agronomists, extensionists and researchers became aware of the studies conducted by North American researchers and producers in the early twentieth century (Lepsch et al., 2015). The translation of study conducted by Norton (1945), entitled "Land Classification as an Aid in Soil Conservation Operations" was a milestone in the history of land classification according to use capacity. In 1949, João Quintiliano de Avellar Marques wrote an article on the survey and classification of land according to its use capacity (Lepsch et al., 2015), being subsequently approximated and published in co-authorship with the Agronomic Institute of Campinas as the first Brazilian manual of soil classification according to use capacity, called "Levantamento Conservacionista: Levantamento e Classificação de Terras para Fins de Conservação do Solo" (Lepsch et al., 2015). The first approximation served as the basis for the writing of the second, third, fourth and fifth approximations of the manual, which aimed at assisting with recommendations for sustainable land use and occupation, the last one (5th approximation) was called "Manual para Levantamento Utilitário e Classificação de Terras no Sistema de Capacidade de Uso" (referred to here as Manual for Utilitarian Survey and Classification of Land in the Use Capacity System) (Lepsch et al., 2015).

The Manual for Utilitarian Survey and Classification of Land in the Use Capacity System in its 5th approximation is currently used at the national level and can be adapted according to the peculiarities of Brazilian regions, especially in relation to topography, with indication for small watersheds and rural properties (Lepsch et al., 2015). Despite its importance for 
optimizing the use of land intended for agricultural purposes and conserving natural resources, since it is based on the principle of using the land according to its natural and/or constructed suitability, there are few examples of its application in practice.

Assessing agricultural suitability of the land must be the first step towards its rational planning, enabling greater environmental, economic and social sustainability (Dent and Young, 1995; Poelking et al., 2015). Analysis of spatial distribution and soil properties is fundamental for the proper management of land, contributing to the planning of rural and urban areas (Florinsky et al., 2002).

In recent decades, soil science has been integrated into the advancement of computer technologies, enabling the development of studies on pedology, especially in relation to soil survey and land use monitoring, allowing for rapid overlapping and updating of maps and decision-making (McBratney et al., 2003; Valera et al., 2017). The use of geographic information systems in studies on soil survey is an important tool for geostatistical analysis and crossing of the various information plans generated from environmental attributes (Scull et al., 2005; Pedron et al., 2006; Poelking et al., 2015). In addition, it supports the survey of landscape information and more efficient delimitation of Permanent Preservation Areas (PPA) (Ribeiro et al., 2005). In this context, the survey of soils and their classification in the use capacity system is an alternative that enables the sustainable management of soil, water and natural resources in general (Lepsch et al., 2015; Poelking et al., 2015; Valera et al., 2017).

The objective of this study was to classify the lands of a micro-watershed located in the Atlantic forest biome, in a region of rough relief, in the use capacity system using geotechnology resources applied to pedological studies and indicate uses for the lands according to their suitability and limitations.

\section{Methodology}

\section{Characterization of the study area}

The study was conducted in a micro-watershed (MWS) with total area of 204 ha (Figure 1), located in the district of Vila da Fumaça, rural area of the municipality of Resende, RJ, Middle Paraíba region (22 ${ }^{\circ} 19^{\prime} 9.31$ "S and $22^{\circ} 17^{\prime} 59.79^{\prime \prime} \mathrm{S}$ latitudes and $44^{\circ} 17^{\prime} 21.91 " \mathrm{~W}$ and $44^{\circ} 17^{\prime} 4.72^{\prime \prime} \mathrm{W}$ longitudes). The climate of the region is classified as humid subtropical, CWa type (Köppen) with temperatures averaging $27^{\circ} \mathrm{C}$ in the warmest months and $17^{\circ} \mathrm{C}$ in the coldest months. The average annual rainfall is $1,549 \mathrm{~mm}$, with rains more concentrated from September to March, according to data from a 23 -year historical series of the Resende station (INMET, 2018).

Figure 1. Location of the studied micro-watershed.

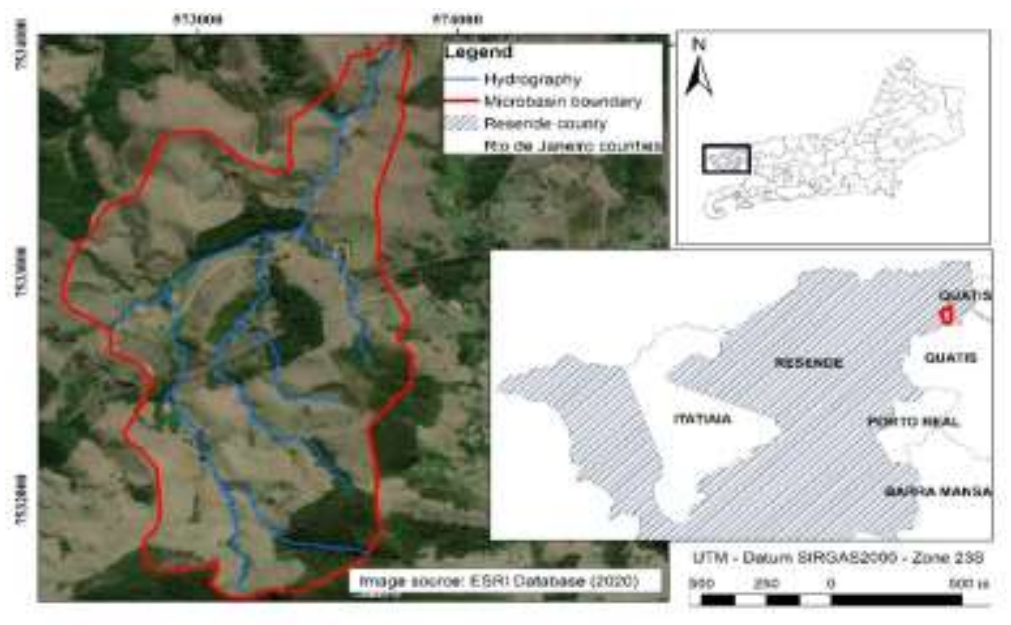

Source: Authors. 


\section{History of land use and occupation in the micro-watershed}

The micro-watershed was exploited with the cultivation of coffee, one of the first agricultural activities implemented in the region around the 1840s, which contributed to accelerate land degradation, mainly due to the exposure of the soil to water erosion. Currently, there are still small fragments of coffee plantations for local consumption, but with predominance of pastures for dairy cattle farming, which in the vast majority are degraded and with low animal support capacity.

\section{Altimetric and slope mapping}

The initial step in the study was the acquisition of topographic maps and delimitation of the hydrography of the watershed. The data were projected in the Universal Transverse Mercator (UTM) projection system, horizontal datum SIRGAS2000, zone 23S. The river basin was manually demarcated based on the digital elevation model (DEM) and satellite images in Google Earth in GIS environment. The DEM was generated from the digital cartographic base provided by the Brazilian Institute of Geography and Statistics (IBGE), in partnership with the State Secretariat for the Environment (SEA), in vector format, with contour curves equidistantly spaced by 10 meters, spot heights and hydrography map, at 1:25.000 scale. From the altimetric database, the DEM was created using the "TopotoRaster" tool of the program ArcGIS Desktop v. 10.3 and, after obtaining the DEM, the procedure for correcting spurious depressions stemming from the interpolation process was performed. This operation aims to obtain a DEM hydrologically consistent, to derive the slope model that assists in interpreting the patterns of the terrain surface (Hall and Olson, 1991). Subsequently, in the program ArcGIS Desktop v. 10.3, the slope map was generated using the module "Spatial Analyst Tools: Surface: Slope". Slope classes were determined according to the classification described in Santos et al. (2015), classifying as areas of flat relief those with slope of up to 3\%; gently undulating relief those with slope from 3 to $8 \%$; undulating relief those with slope from 8 to $20 \%$; strongly undulating relief those with slope from 20 to $45 \%$, mountainous relief those with slope from 45 to $75 \%$ and steep relief those with slope greater than $75 \%$.

\section{Description and collection of samples}

After creating the slope map, soil characterization and classification was performed. Initially, the landscape and relief were evaluated, and two toposequences were established for sampling, one slope to the south and one to the west, in which soil pits were opened at the summit, backslope, footslope, toeslope and lower positions. Besides the two toposequences, two other soil pits were opened, one on the banks of the first-order (main) drain of the watershed (Garcez \& Alvarez, 1988), on the western slope, and the other in a fragment of Atlantic forest on the southern slope, the latter being adopted as a reference for the classification of water erosion, according to Lepsch et al. (2015). The description and collection of samples from the profiles were performed according to Santos et al. (2015).

After morphological description of the profiles, samples were collected for analysis of chemical attributes, particle-size composition and soil permeability. The chemical attributes analyzed in all horizons were: $\mathrm{pH}$ in water, calcium $(\mathrm{Ca} 2+)$, magnesium $\left(\mathrm{Mg}^{2+}\right)$, aluminum $\left(\mathrm{Al}^{3+}\right)$, sodium $\left(\mathrm{Na}^{+}\right)$, potassium $\left(\mathrm{K}^{+}\right)$, phosphorus $(\mathrm{P})$ and potential acidity $(\mathrm{H}+\mathrm{Al})$. These results were used to calculate the sum of exchangeable bases (S), cation exchange capacity $(\mathrm{T})$ of the soil at $\mathrm{pH} 7.0$ and base saturation (V\%), according to Silva (2009). Particle-size composition was analyzed in all horizons by the pipette method according to Teixeira et al. (2017). The results are presented in Table 1.

Soil permeability was evaluated by hydraulic conductivity using the constant-head method according to Teixeira et al. (2017). Undisturbed samples were collected with an Uhland sampler in the surface and subsurface layers of the soil, considering the $\mathrm{A}$ and transitional horizons ( $\mathrm{AB}$ and $\mathrm{AC}$ ) as a surface layer and the $\mathrm{B}$ or $\mathrm{C}$ plus the transitional horizons (BC) as subsurface layer. The soils were classified up to the categorical level of Major Group according to the Brazilian Soil Classification Sy stem (Santos et al., 2018). 
Erosion and effective soil depth were classified according to the Manual for Utilitarian Survey and Classification of Land in the Use Capacity System (Lepsch et al., 2015).

Based on the chemical attributes of the surface and subsurface layers, soil fertility classification was performed, taking as reference the Manual of Liming and Fertilization for the Rio de Janeiro State (Freire et al., 2013).

From the taxonomic classification, the map of soils of the micro-watershed was generated through vectorization in the ArcGIS Desktop v.10 program. After creating soil and slope maps, land use capacity was classified, which showed that the limitations due to topography (slope) of the micro-watershed were predominant.

\section{Results}

The micro-watershed is between the 500 and $100 \mathrm{~m}$ of altitude, with a predominance of rough relief and slope greater than $20 \%$ (Figure 2). The percentages of area in each slope class were $2.1 \%$ for the class from 0 to $3 \% ; 1.7 \%$ for the class 3 to $8 \%$; $9.7 \%$ for the class 8 to $20 \% ; 36.6 \%$ for the class 20 to $45 \% ; 42.9 \%$ for the class 45 to $75 \%$ and $7 \%$ for the class with slope greater than $75 \%$. Only $3.8 \%$ of the area of the micro-watershed has topography ranging from flat to gently undulating (classes of $0-3$ and 3-8\% slope), while $79.5 \%$ was classified as strongly undulating and mountainous relief.

Table 1 presents the chemical attributes and granulometric composition of soils classified in the watershed. In the toposequence established in the southern slope, occurrence of Latossolo Vermelho distrófico (Oxisol) was observed at the summit, footslope and toeslope of the hill, as well as in the Atlantic forest fragment in the footslope of the hill of the same slope and Neossolo Regolítico distrófico (Psamment) at the lower portion. In the toposequence on the western slope, Cambissolo Háplico distrófico (Inceptisol) was observed at the summit, footslope and lower portion, while Argissolo Vermelho-Amarelo distrófico (Ultisol) was verified in the toeslope. Gleissolo Melânico distrófico (Entisol) was verified close to the main drain.

Figure 2. Relief and slope distribution in the studied micro-watershed.

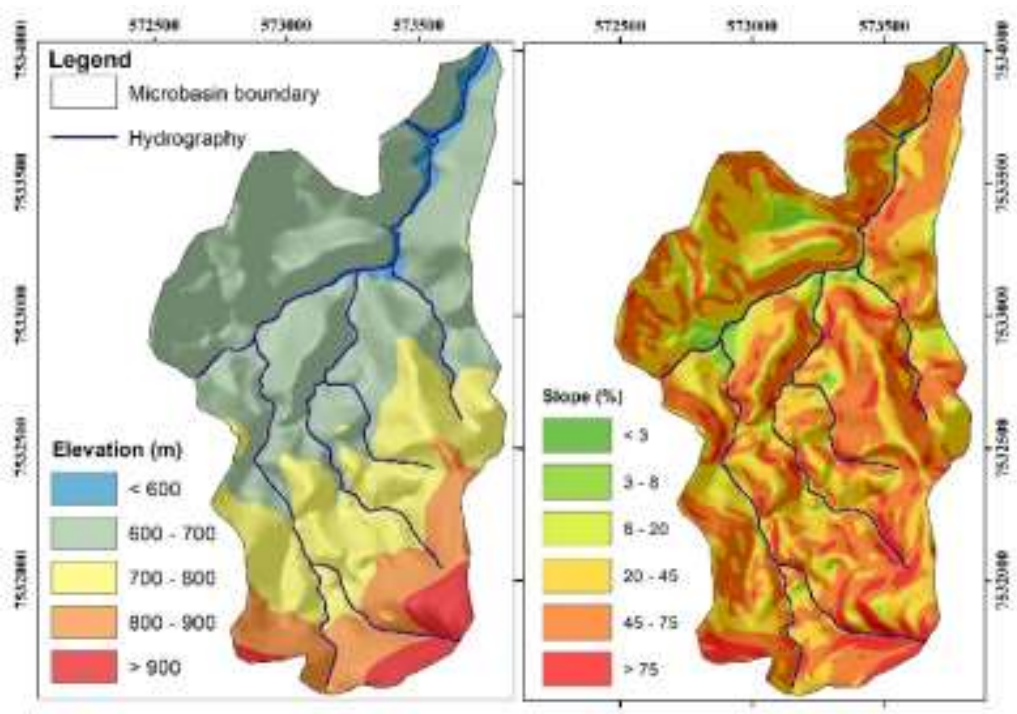

Source: Authors.

Regarding the effective depth, there was predominance of very deep (greater than $2.0 \mathrm{~m}$ ) and deep soils (between 1.0 and $2.0 \mathrm{~m}$ ), except for the Neossolo Regolítico and the Cambissolo Háplico at the summit of the hill, which showed effective depth classified as moderately deep (between 0.50 and $1.0 \mathrm{~m}$ ). For the Neossolo Regolítico, a significant increase in the presence of boulders, cobbles and gravel was observed at $60 \mathrm{~cm}$ depth. In the Cambissolo Háplico located in the summit region, 
fragmentary lithic contact was verified at $80 \mathrm{~cm}$ depth.

For all profiles, permeability was classified as moderate $\left(5\right.$ to $\left.150 \mathrm{~mm} \mathrm{~h}^{-1}\right)$. The texture varied from medium to clayey in the surface and subsurface layers, except for the Neossolo Regolítico distrófico, which showed sandy texture in the surface layer.

Water erosion was classified as moderate for sheet erosion and occasional and shallow gullies for gully erosion, in the toeslopes and summits of hills. In the footslopes of the hills, erosion was classified as severe for sheet erosion and frequent and shallow gullies for gully erosion. In the footslope of the hill under the Atlantic forest, erosion was classified as non-apparent, demonstrating the importance of vegetation for soil protection and preservation. In the lower portions, accumulations of colluvial sediments were observed, resulting from the removal of the surface layer of the soils located in the positions of toeslope, footslope and at the summits of the elevations. The classification of water erosion demonstrates the effect of anthropic action, contributing to a greater expression of erosive processes in the surface layers of soils located at the steepest points of the hills.

Fertility was classified as low (Freire et al., 2013), due to the low values of $\mathrm{pH}, \mathrm{Ca}^{2+}, \mathrm{Mg}^{2+}, \mathrm{P}$ and $\mathrm{K}^{+}$, and high values of $\mathrm{Al}^{3+}$. Low fertility in the forest fragment and on the banks of the main drain results from the high values of potential acidity and $\mathrm{Al}^{3+}$, although values of $\mathrm{Ca}^{2+}$ and $\mathrm{Mg}^{2+}$ considered suitable for pasture and most agricultural crops were observed (Freire et al., 2013). Under all landscape conditions, low fertility is directly associated with soil management and occupation, topography and, consequently, with water erosion.

It was observed that the order of Latossolo Vermelho (LV) prevailed in the southern slope, while Cambissolo Háplico distrófico (CX) and Argissolo Vermelho-Amarelo distrófico (PVA) (Figure 3) prevailed on the western slope. The association of soils in LV+PVA and PVA+CX mapping units can be recommended because these soils are similar from the agronomic point of view, so their use and management are possible because they have similarity of chemical and physical attributes in the surface layer (Ribeiro et al., 2012), which favors the implementation and conduction of agricultural activities and soil conservation practices.

The map in Figure 4 shows the classification of the lands according to their use capacity based on the slope classes. Based on the recommendations of the Manual for Utilitarian Survey and Land Classification in the Use Capacity System (Lepsch et al., 2015) in relation to the risks of soil degradation, the following classes were observed: II, III, IV, VI and VIII. Class II was represented by areas with slope between 0 and $8 \%$; class III by the areas with slope between 8 and 20\%; class IV by areas with slope between 20 and 45\%; class VI by areas with slope between 45 and 75\% and class VIII by areas with slopes above $75 \%$. Due to the peculiarities regarding the risks of degradation according to Lepsch et al. (2015) and also according to the Brazilian Forest Code (Brasil, 2012), classes I, V and VII were not found in the watershed.

Class I was not mapped because there were no areas without or with slight permanent limitations in relation to the risk of degradation with intensive agricultural use. Class $\mathrm{V}$ was included in the areas of permanent preservation of riparian forests. According to Lepsch et al. (2015), class V encompasses lands without or with a low risk of degradation by erosion, but with other limitations that cannot be overcome, so they are only recommended for use as pastures and/or reforestation. Class VII, despite being present in small areas, was not mapped because it represents lands that have severe risk of degradation, even when used as pasture and/or reforestation, being in this case included in class VIII for the preservation of native vegetation and wildlife and act in the storage of rainwater in the soil. 
Table 1. Chemical attributes and granulometric composition of soils classified in the watershed.

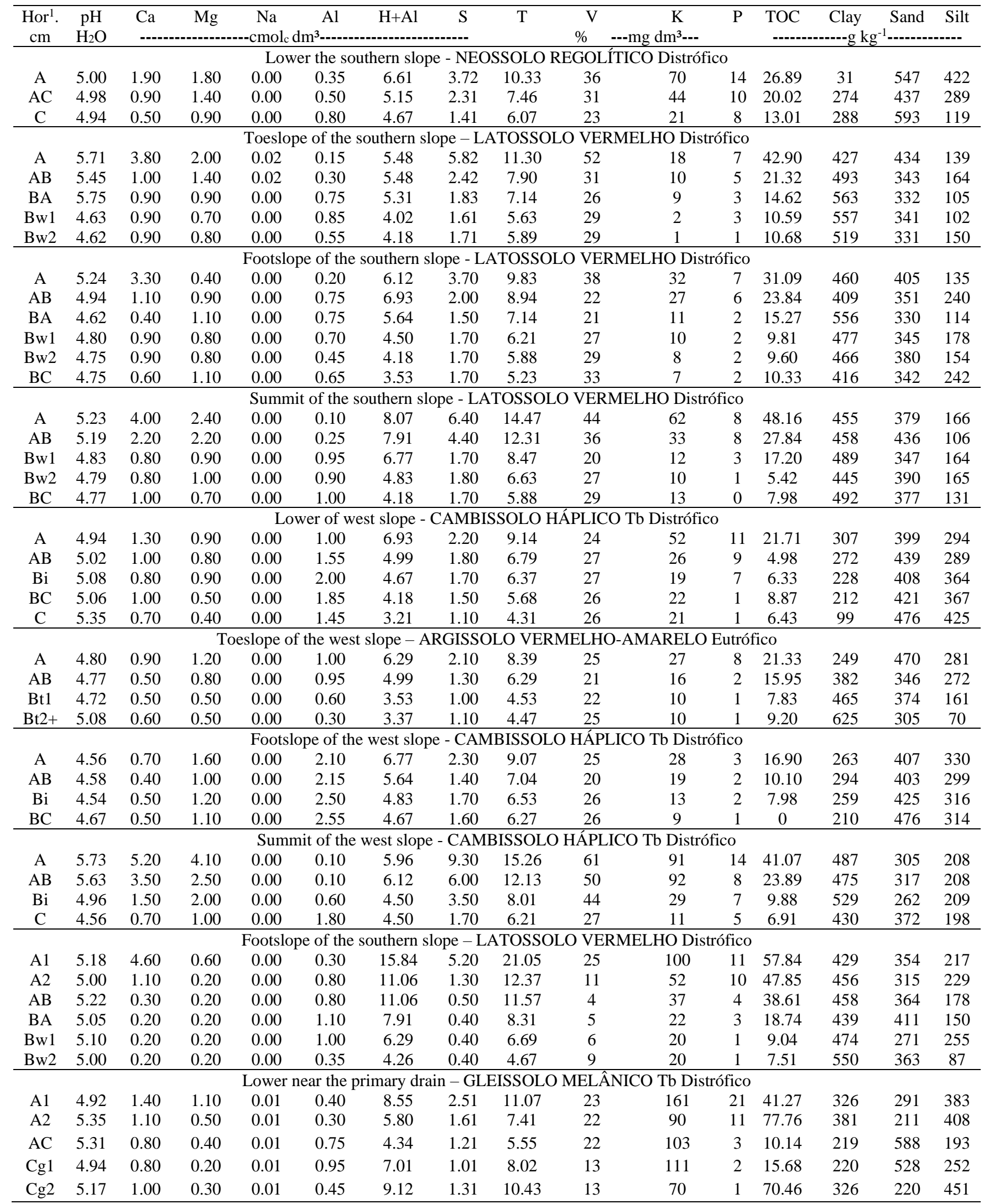


Figure 3. Soil classes in the studied micro-watershed.

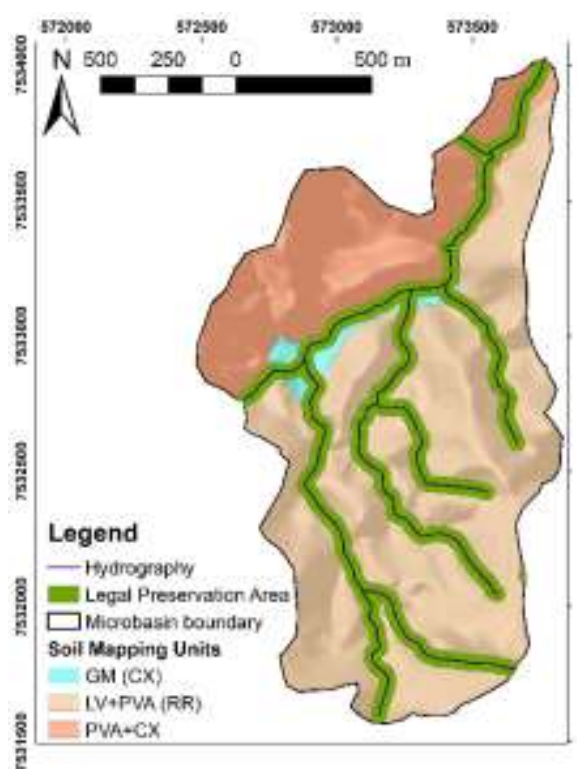

Source: Authors.

Permanent preservation areas (PPA) were established in 30-m-wide strips on the banks of the hydrographic channels (streams) (Figure 4). Although they were not represented on the map due to the scale adopted, in practice the PPA areas should be extended within a 50-m radius around the springs, which are located at the highest portions of the micro-watershed, in order to comply with the Brazilian Forest Code (Brasil, 2012).

Figure 4. Land use capacity classification.

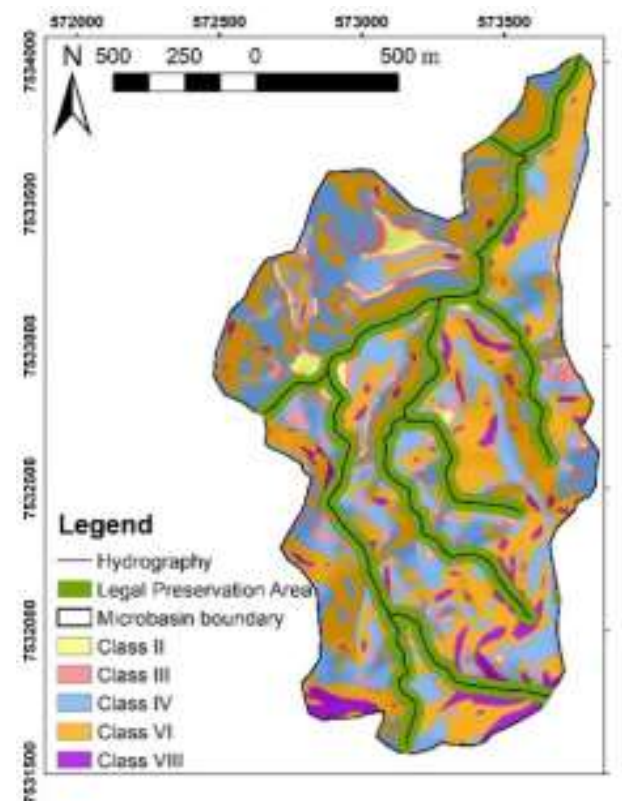

Source: Authors.

\section{Discussion}

Rough relief is a limiting factor in most of the area for agricultural activities of intensive land use in the watershed, which is why the slope outweighed the parameters effective depth, texture, permeability and fertility for the classification of the 
lands based on their use capacity according to Lepsch et al. (2015). Additionally, most of the area has slope between 20 and $75 \%$, being classified as areas with suitability for pastures according to Lepsch et al. (2015).

With regard to soils (Latossolo, Argissolo \&Cambissolo), the classification of use capacity was not affected, since the classes II, III, IV and VI are recommended for agricultural activities and class VIII for environmental preservation and rainwater storage. The Neossolo Regolítico distrófico, which is a soil with restrictions on agricultural use, occurs on the banks of streams in a strip less than $30 \mathrm{~m}$ wide, where riparian forests should be maintained, hence without agricultural activities directly.

The main factor of degradation of agricultural soils in the tropical and subtropical region of the globe is water erosion, which is influenced by rainfall, soil type, relief, soil cover, management, and conservation practices (Valera et al., 2017). In regions of rough topography and soils with a history of use that favor degradation, the slope of the hills is the factor that most negatively impacts their conservation, since it favors surface runoff, with transport of suspended solid materials (mineral particles and organic matter) and, in solution, nutrients and contaminants, and all these materials can be deposited in the lower portions and water sources (Bertol et al., 2017).

According to Dent and Young (1995), the assessment of land use suitability should be the first step towards its rational planning and sustainable use from the environmental, economic and social aspects. The advancement of computational and geoprocessing technologies has enabled the integration of soil science with computer systems and maximization of studies on pedology, soil surveys and land use monitoring, enabling rapid overlapping and updating of maps for use and occupation maps of lands and, consequently, the use and occupation according to their suitability (McBratney et al., 2003; Poelking et al., 2015; Gan-lin et al., 2017).

Survey of the physical environment and classification of the lands of the watershed in the use capacity system show that it is possible to occupy and use these lands in a sustainable way. According to the recommendations of Lepsch et al. (2015), in classes II and III, which represent approximately $6 \%$ of the total area, disregarding PPAs, it is possible to use intensive agricultural crops, provided that simple conservation practices are adopted for class II and more complex conservation practices are adopted for class III. As simple practices, liming, mineral and organic fertilization, contour farming and rotation of crops of agronomic interest to form soil cover could be recommended (Bertoni \& Lombardi Neto, 2012). As more complex practices, mechanical practices such as terracing and construction of trapezoidal boxes for rainwater collection on roads and circular dams could be recommended to reduce surface runoff and promote the accumulation and infiltration of rainwater in the steepest production areas Classes IV and VI, which together represent approximately $62 \%$ of the area, and the areas of PPA, are indicated for use with natural or planted pastures, consistent with the livestock farming activity, traditional in the region. In this case, rotational grazing accompanied by planning of fertilization and control of invasive plants, pests and diseases will promote the formation of pasture of high productivity and consequently good quality, and soil conservation (Bertoni \& Lombardi Neto, 2012).

Planned restoration of the vegetation of riparian forests and recovery of native vegetation in class VIII creates the possibility of conducting economic activities such as beekeeping and fish farming, since it promotes greater supply of flowers for the feeding and production of bees and improves water production in the springs existing in all the headwaters of the hydrographic channels. Restoration of native vegetation interconnecting the fragments through corridors will provide a continuum of native vegetation in approximately $38 \%$ of the area, benefiting the flora and fauna, inside and outside the watershed.

As a result, classification of the watershed lands in the use capacity system will promote the use of approximately 12.24 ha (6\% of the area) for crops, 126.48 ha (62\% of the area) for pastures and 77.52 ha (38\% of the area) for environmental preservation and exploitation of other activities such as fish farming and aquaculture. The occupation and use of the watershed respecting the suitability of the land meets the human needs for agricultural production and preserves the environment, without creating conflicts for natural resources. 


\section{Conclusions}

Geotechnology applied to soil mapping and land classification in the use capacity system is an important tool for the planning, occupation and use of natural resources.

In regions of rough relief, the slope outweighs the parameters effective depth, texture, permeability, erosion and fertility for the classification of lands in the use capacity system and should be adopted as indicative of land use classes.

Survey of the physical environment and classification of lands in the use capacity system promotes efficient use of natural resources through a more efficient exploitation of agricultural activities already present and new alternatives by increasing the biodiversity of plant species and water supply, meeting human needs and preserving the environment.

\section{References}

Bertoni, J., \& Lombardi Neto, F. (2012). Conservação do solo. ( $\left.8^{\mathrm{a}} \mathrm{ed}.\right)$ : Ícone, 355 p.

Bertol, I., Luciano, R. V., Bertol, C., \& Bagio, B. (2017). Nutrient and Organic Carbon Losses, Enrichment Rate, and Cost of Water Erosion. Revista Brasileira de Ciência do Solo, 41; e0160150. 10.1590/18069657rbcs20160150

Brasil. LEI n 12.651, de 25 de Maio de 2012. Novo Código Florestal, 2012. http://www.planalto.gov.br/ccivil_03/_ato2011-2014/2012/lei/112651.htm\&gt;.

Dent, D., \& Young, A. (1995). Soil survey and land evaluation: E. FN SPON, 284p.

Freire, L. R., Balieiro, F. C., Zonta, E., Anjos, L. H. C., Pereira, M. G., Lima, E., Guerra, J. G. M., Ferreira, M. B. C., Leal, M. A. A., Campos, D. V. B, \& Polidoro, J. C. (Org.) (2013). Manual de calagem e adubação do Estado do Rio de Janeiro. (1a ed.): Embrapa, 2013. 430p.

Florinsky, I. V., Eilers, R., Manning, G., \& Fuller L. (2202). Prediction of soil properties by digital terrain modelling. Environmental Modelling and Software, 17(3):295-311. 10.1016/S1364-8152(01)00067-6

Garcez, L. N., \& Alvarez, G. A. (1988). Hidrologia. (2a ed.) revisada e atualizada: Edgard Blücher, 291p.

Gardner, D. R. (1988). The national cooperative soil survey of the United States. Washington, D.C: USDA/NRCS. (Historical notes, 7), 270p.

INMET - Instituto Nacional de Meteorologia. http://www.inmet.gov.br/portal/.

Klingebiel, A. A., \& Montgomry, P.H. (1961). Land-capability classification. Washington: Soil Conservation Service/U.S. Gov. Print Office. (Handbook, 210). $21 \mathrm{p}$.

Lepsch, I., Espíndola, C. R., Vischi Filho, O. J., \& Siqueira, D. S. (2015). Manual para levantamento utilitário e classificação de terras no sistemas de capacidade de uso. Viçosa, MG:Sociedade Brasileira de Ciência do Solo. 170p.

Mcbratney, A. B., Santos, M. L. M., \& Minasny, B. (2003). On digital soil mapping. Geoderma, 117 (1-2): 3-52. 10.1016/S0016-7061(03)00223-4

Norton, E. A. (1939). Soil conservation survey handbook. Washington, D.C: USDA/Soil Conservation Service: (Miscellaneous publication, 352). 39p.

Pedron, F. A., Poelking, E. L., Dalmolin, R. S. D., Azevedo, A. C., \& Klamt, E. (2006). A aptidão de uso da terra como base para o planejamento dos recursos naturais no município de São João do Polêsine, RS. Ciência Rural, 36(1):105-112. 10.1590/S0103-84782006000100016

Poelking, E. L., Dalmolin, R. S. D., Pedron, F. A., \& Fink, J. R. (2015). Sistema de informação geográfica aplicado ao levantamento de solos e aptidão agrícola das terras como subsídios para o planejamento ambiental do município de Itaara, RS. Revista Árvore, 39(2): 215-223. 10.1590/0100-67622015000200001

Ribeiro, C. S., Soares, V. P., Oliveira, A. M. S., \& Gleriani, J. M. (2005). O desafio da delimitação de áreas de preservação permanente. Revista Árvore, 29(2): 203-212. 10.1590/S0100-67622005000200004

Santos, H. G., Tito-Jacomine, P. K., Anjos, L. H. C., Oliveira, V. A., Lumbreras, J. F., Coelho, M. R., Almeida, J. A., Araujo Filho, J. C., Oliveira, J. B., \& Cunha, T. J. F. (2018). Sistema Brasileiro de Classificação de Solos. (5 edição) revista e ampliada. Brasília: Embrapa. 356p.

Santos, R. D., Lemos, R. C., Santos, H. G., Ker, J. C., \& Anjos, L. H. C. (2015). Manual de descrição e coleta de solo no campo. (7a ed.) SBCS/Embrapa-CPS. Viçosa (MG). 100p.

Scull, P., Franklin, J., \& Chadwick, O.A. The application of classification tree analysis to soil type prediction in a desert landscape. Ecological Modelling, 181(1):1-15, 2005. 10.1016/j.ecolmodel.2004.06.036

Teixeira, P. C., Donagema, G. K., Fontana, A., \& Teixeira, W. G. (2017). Manual de métodos de análise de solo. (3ª edição) revisada e ampliada - Brasília, DF: Embrapa. 573p.

Valera, C. A., Pissarra, T. C. T., Martins Filho, M. V., Valle Junior, R. F., Sanches Fernandes, L. F., \& Pacheco, F. A. L. (2017). A legal framework with scientific basis for applying the 'polluter pays principle' to soil conservation in rural watersheds in Brazil. Land Use Policy, 66:61-71, 2017. 10.1016/j.landusepol.2017.04.036

Zhang, G., Feng, L., \& Song, X. (2017). Recent progress and future prospect of digital soil mapping: A review. Journal of Integrative Agriculture, 16 (2): 2871 2885. 10.1016/S2095-3119(17)61762-3 